\title{
Prinsip-prinsip Pengendalian Mutu pada Proses Pemintalan Kapas
}

\author{
Oleh : Sutarno
}

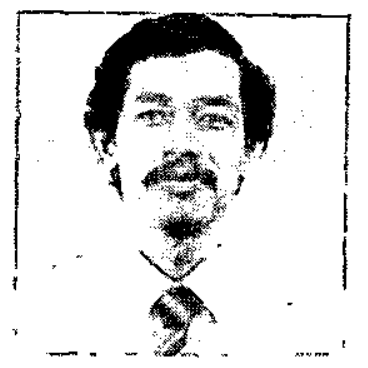

Sutarno, dilahirkan 28 September 1957 di Ngáwi. Menyelesaikan S1 pada Fakultas Teknologi Indústri UII, Jurusan Teknologi Tekstil pernah bekerja di Lembaga Pendidikan dan Pengembangan Industri Kecil (LP2KIK) Yogyakarta tahun 1992 - 1984 pemah menjadi anggauta team peneliti tentang "Karekteristik Industri Kecil DIY", beberapa kali mengikuti seminar tingkat Nasional. Ikut merintis dan mengelola majalah "Kemateks" tahun 1982 - 1983 dan aktive di Lembaga Kemahasiswaan di UII. Jabatannya sekarang sebagai Dosen tetap pada almamaternya Universitas Islam Indonesia.

\section{Pendahuluan}

Dewasa-ini di negara-negara yang telah maju tingkat industri tekstilnya menunjukkan suatu peningkatan yang menonjol terutama di bidang pengendalian mutu dalam proses pemintalan benang. Metoda-metoda pengendalian proses produksi benang telah diketemukan dengan pendekatan-pendekatan ilmiah. Sistem pengendalian mutu dalam industri pemintalan meliputi semua teknik-teknik pengendalian mulai dari bahan baku, proses produksi, insfeksi bahan jadinya, kontrol biaya dan lain-lain.

Pengendalian mutu yang efisien harus mencakup: *)

a. Menetapkan level produksi yang optimum pada kecepatan produksi dan efisiensi yang tertinggi.

b. Menjaga tetapnya produksi level dengan mengadakan check-up dan analisa dari waktu yang terbuang (down time).

c. Test dan kontrol yang diadakan tahap- tahap produksi yang strategis dari mulai bahan baku sampai bahan jadi, untuk dapat segera mengetahui kelainankelainan atau cacat-cacat dalam produksi.

d. Menyelenggarakan statistik secukupnya untuk membantu faktor-faktor yang menyebabkan kondiși di bawah stańdar yang telah ditetapkan.

e. Penetapan standar-standar dari produk dalam proses dan telah selesai di finish.

Mutu dalam tiap fase dari industri pemintalan dapat diperoleh dengan jalan seleksi dari bahan baku menurut spesifikasinya, mixing secara rasional dari bahan baku, dan produksi benang yang uniform dalam proses pemintalannya.

*) Disampaikan oleh Suparman. S. Teks. Dalam Diskusi Panel di Kampus FTT - UII, pada tahun 1982 


\section{Pengendalian Mutu Secara Statistik}

\section{Pengertian tentang Mutu}

Hasil produksi dari suatu proses produksi yang bermutu adalah barangbarang yang dapat dijual dengan mudah (marketable), uniform dan mutunya dapat dipercaya. Mutu dapat diukur dengan hubungan matematis antara empat faktor antara lain :

a. Suatu jumlah yang dapat diukur untuk keperluan inspeksi (X).

b. Harga dari "bagian barang yang cacat" (fraction - defective) atau "prosentase barang cacat" (percentage of defactive) dalam suatu sample (P).

c. Jumlah cacat $(\mathrm{Pn})$.

d. Jumlah rata-rata cacat per unit (C).

\section{Quality Control Charts}

Quality control charts adalah teknik statistik yang paling lazim dipergunakan dalam pengendalian mutu dalam industri pemintalan. Dasar-dasar statistik yang dipergunakan untuk macam-macam control charts yang dikenal selama ini adalah :

a. Normal Frequency destribution.

b. Binomial destribution.

c. Poisson destribution.

Control chart adalah penggambaran secara grafis dari control limits. Dalam hal mengumpulkan data untuk pembuatan control charts, maka perlu ditetapkan faktorfaktor:

- Jenis data yang akan dikumpulkan.

- Jumlah data yang diperlukan.

- Proses pengukuran.

- Urutan dari pengukuran, dan

- Cara-cara analisa data-data yang dikumpulkan.

Control charts merupakan suatu cara mengendalikan proses dan keruwetankeruwetan dalam proses produksi. Pada quality charts terdapat apa yang discbut "Control limits" dan terletak di dalam batasbatas "Specification limits".

Specification limits adalah batas-batas maksimum dan minimum yang ditetapkan untuk setiap produk oleh produsen atau konsumen.

Control limits juga merupakan kriteria untuk menetapkan apakah suatu proses produksi terganggu oleh sebabsebab tertentu atau tidak, sehingga memerlukan tindakan-tindakan penelitian koreksi.

Quality control charts pada umumnya, control limitsnya dibuat atas dasar "tiga sigma limits". Ini berarti bahwa $99,8 \%$ dari data tercakup di dalamnya. Apabila dipergunakan dua sigma limits, maka $95 \%$ dari data tercakup di dalamnya, seperti halnya pada control limits untuk berat lap. Variasi dalam mutu ada dua macam, yaitu variasi karena "change" yang terdapat diantara limit dan variasi karena "sesuatu sebab" (terjadi apabila suatu proses mempunyai hasil-hasil test yang berada di Iuar control limits).

Jadi kegunaan dari control charts adalah :

- Sebagai pembantu untuk pengendalian mutu.

- Untuk dapat mengurangi variasi dalam produksi.

- Untuk dapat meramalkan besarnya variasi dari produk.

- Untuk memberikan data yang dapat dipertanggungjawabkan untuk bertindak.

- Mengurangi biaya pemeriksaan mutu.

- Sebagai alat pembantu menemukan kesalahan-kesalahan dalam produksi.

- Untuk memberikan gambaran yang permanen dari mutu produksi.

- Machine acceptance.

Quality control charts yang lazim 
dipergunakan dalam pengendalian mutu dalam industri pemintalan ada lima jenis:

1. Charts untuk kwantitas yang dapat diukur dalam inspection.

2. Charts untuk mengetahui 'variasi di dalam sub group.

3. Charts untuk \% barang cacat (\% defective).

4. Charts untuk jumlah barang yang cacat (number of defective).

5. Charts untuk jumlah cacat tiap unit.

\section{Tahapan Proses dan Pengendalian Mutu Pemintalan}

Tahapan proses pemintalan kapas ada beberapa macam tergantung dari bahan baku (benang yang akan dibuat) dan urutan proses mesin-mesinnya.

1. Hal-hal yang perlu diperhatikan dari kapas

Hal yang perlu diperhatikan dari bahan baku (kapas) adalah sifat-sifat fisik kapas yang mempengaruhi proses pemintalannya, seperti:
a. Grade
b. Panjang staple
c. Kerataan panjang serat
d. Kehalusan dan kedewasaan
e. Kekuatan
f. Kandungan air.

\section{a. Grade-Kapas}

Grade kapas ditentukan oleh; wama, jumlah kotoran dan preparationnya. Penentuannya dibandingkan dengan Universal Standart box. Untuk tiap faktor diberi grade index dan gradenya ditentukan dari harga rata-rata dari grade indexnya.

\section{b. Panjang staple}

Panjang staple ditentukan dengan hand-pull atau diperhitungkan effective length atau upper half mean length-nya.

Hubungan antara staple length dan twist multyplier untuk maksimal strength perlu diperhatikan.

\section{c. Kerataan panjang serat}

Faktor ini lazimnya dinilai dari Uniformity Ratio-nya, coeficien of variationdan \% short fibresangatmempengaruhi.

\section{d. Kehalusan kedewasaan}

Kehalusan atau fineness kapas erat sekali hubungannya dengan kedewasaan, atau fiber maturity. Makin halus serat yang dipintal, makin banyak jumlahnya setiap penampang melintang (Cross - Section) benangnya sehingga memperbesar friksi antar serat dan meningkatkan kekuatan benangnya.

Dalam hal ini perlu diperhatikan untuk dapat mengetahui kehalusan' serat untuk menentukan mix yang optimal. Kehalusan diukur dengan micronoir-nya yang didasarkan atas $\mathrm{U}$ gr/inch.

Jumlah serat per cross - section, adalah: ${ }^{1)}$

$$
\mathrm{n}=\frac{15.000}{(\mathrm{Ne} 1) \text { (härga micronaire) }}
$$

Jumlah serat minimum untuk dapat. dipintal adalah 88 .

Kedewasaan serat mempengaruhi tebal tipisnya lapisan cellulosa, serat yang kurang dewasa ada tendensi membentuk kumpulan serat kusut atau biasa disebut Neps dan sangat mempengaruhi kekuatan serat.

1) Suparman. S. Teks, "Evaluasi Protes Pemintalan", makalah untuk seminar Konformasi pesanan Kain untuk Pakaian Dinas, Institut Teknologi Tekstil Bandung, 1970. 


\section{e. Kekuatan}

Kekuatan serat kapas akan langsung mempengaruhi kekuatan benang. Kekuatan serat ditentukan oleh tingkat kedewasaan serat. Ukuran kekuatan serat kapas dinilai dengan harga Pressley-nya.

\section{f. Kandungan air}

Kandungan airpadabahan baku yang lazim disebut $\%$ regain atau \% seprise sangat penting artinya baik dalam perdagangan maupun dalam proses pemintalannya. Dalam perdagangan dikenal istilah "Standard regain" dan "Comercial regain". Besamya comercial regain dapat ditentukan sendiri oleh pembeli dan penjual dengan pedoman pada standard regain. Standard regain untuk serat kapas internasional (I.S.O) ditetapkan sebesar 8,5\%.

2. Pengaruh sifat-sifat fisik serat kapas terhadap mutu benangnya.

Pengaruh sifat-sifat fisik serat kapas terhadap benang dan appearance-nya dapat digambarkan secara grafik seperti berikut :
Dari grafik tersebut terlihat bahwa ternyata yang banyak mempengaruhi kekuatan benang adalah :

- Kekuatan serat

- Panjang serat

- Kehalusan serat

Sedangkan faktor yang banyak mempengaruhi appearance benang adalah :

- Pánjang serat

- Grade index

- Kehalusan serat

- Faktor-faktor mekanis dan lain-lainnnya yang tidak diukur

\section{Pengendalian Proses Pemintalan}

Pengendalian mutu proses pemintalan kapas, dilakukan mulai dari pengujian bahan baku (kapas termasuk mixing-nya, pengendalian lap, pengendalian mutu pada carding, pengendalian speed mesin, dan pengendalian Ring-Frame).
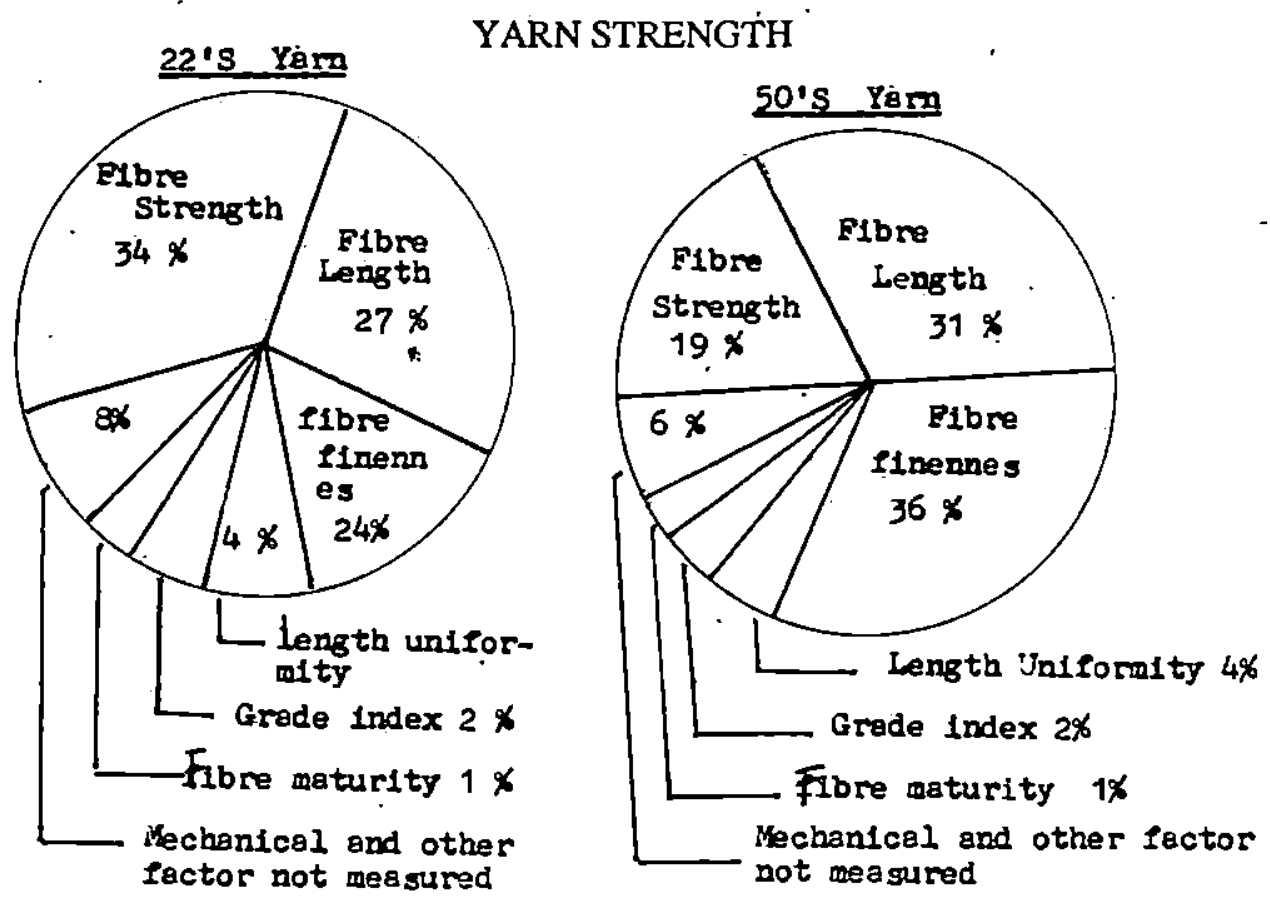


\section{YARN APPERANCE}

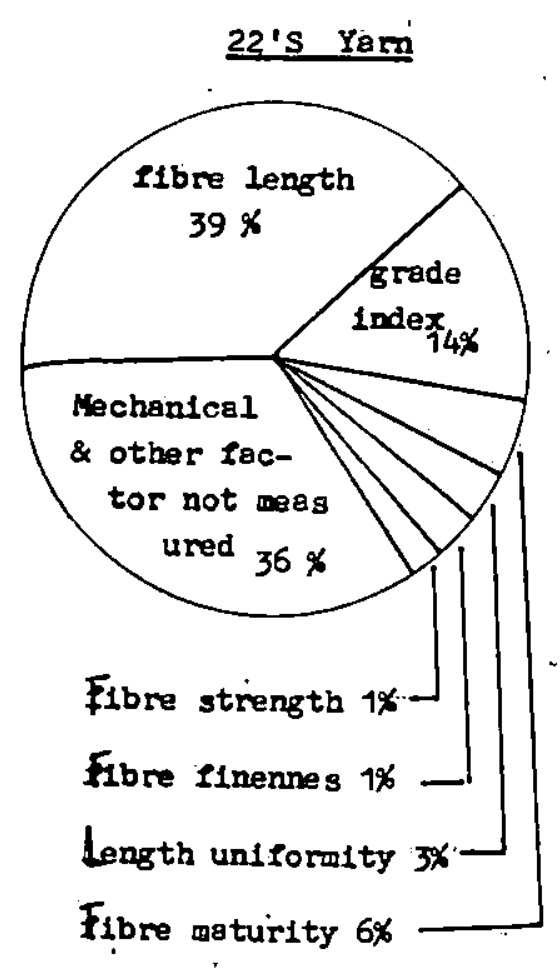

1. Pengujian Serat Kapas

Pengujian atau testing serat kapas sebagai bahan baku dari pemintalan benang kapas adalah langkah pertama dari pengendalian mutu dalam perusahaan pemintalan, yang terdiri dari atas :

a. Penentuan staple length dengan menggunakan staple sorter, fibrograph, atau penarikan dengan tangan.

b. Penentuan grade dengan membandingkan dengan standar Grade box.

c. Penentuan kehalusan serat dengan menggunakan micronaire.

d. Penentuan kekuatan serat dengan menggunakan Pressley tester.

e. Penentuan misture regain dari serat kapas.

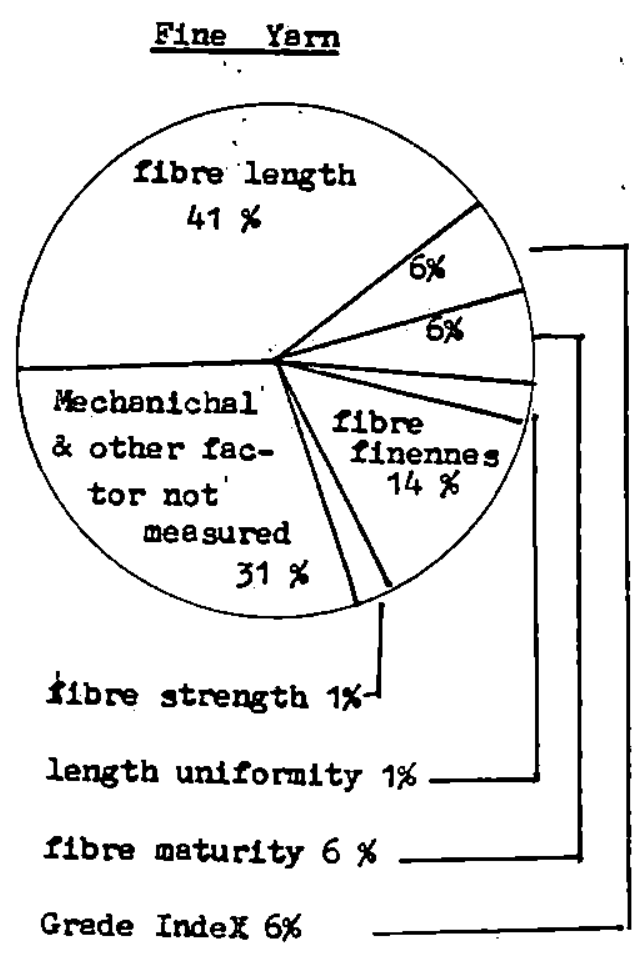

Pengujian-pengujian tersebut adalah untuk klasifikasi dari mutu kapas dan kemudian dibuat mixing yang rational. Pengujian dilakukan dari 4 bales dari yang baru dengan sampling sebanyak 8 sample untuk memperoleh mixing yang rational dari kapas, maka harusmemperhatikan halhal, antara lain:

a. Serat kapas dari tiap bale ditentukan gradenya dan diadakan pencatatan atas hasil-hasil grading tersebut.

b. Cara-cara mixing kapas harus distandarisasi dan di check.

c. Diusahakan suatu ratio mixing kapas selalu uniform, dan penguapannya untuk dapat meningkatkan kekuatan benang.

d. Mutu dari kapas dalam tiap bale harus di check dan disesuaikan dengan standar 
yang telah ditentukan.

e. Kode-kode tertentu harus dicantumkan sebagai tanda pada tiap bale sesuai dengan jenis kapasnya.

Mixing dari bales adalah cara yang paling lazim dikerjakan dalam pabrik pemintalan benang dan dilakukan sebagai berikut:

a. Urutan dan Ratio mixing harus diberi tanda-tanda yang jelas.

b. Satu mixing sedikitnya terdiri dari 20 bales yang telah dibuka dan di distribusi sesuai dengan ratio mixing dan bales harus ditempatkan pada tempat-tempat yang telah diberi tanda.

c. Diambil sejumlah kapas yang konstan dari tiap bale dan kemudian diterapkan $k e$ atas Creeper lattice, setelah dibuka dengan tangan, secara berlapis-lapis seperti sandwich.

d. Usable waste baru di-mix menurut mixing ratio dan diterapkan secara merata. Untuk pengujian tersebut perlu dibuat control charts.

\section{Pengendalian Lap}

Pengendalian lap ditujukan untuk mengurangi variasi berat lap dari tiap finisher scuther, atau untuk menghasilkan lap yang lebih uniform. Untuk itu perlu dibuat control charts untuk berat berikut lembaran datanya.

Pengendalian mutu làp dilakukan dengan cara mencatat berat lap dan variasi berat lap per yard/meter.

\section{Pengendalian Mutu pada Carding}

Pengendalian mutu pada carding terdiri dari penentuan jumlah Neps dan Mates, serta berat sliver. Untuk survey Neps dan Matespadamesin carding makalangkah berikut perlu diambil:
1. Dilakukan pemeriksaan terhadap sejumlah mesin (misal 5 mesin) tiap hari (tergantung dari jumlah mesin keseluruhannya), jumlah neps dan mates pada card web. Pemeriksaan tiap mesin sekali seminggu bergiliran.

2. Untuk men-test neps dan mates, dengan cara menaruh carding web pada papan yang hitam dan kemudian menutupnya dengan kaca/plastik yang diberi gambar deretan bulatan-bulatan sebesar 1.inch persegi sebanyak 36 bulatan sehingga jumlah neps dan mates per 36 inch persegi dapat segera ditentukan. Dapat juga dipergunakan standar 100 inch2.

3. Hasil pengamatan dituangkan dalam $\mathrm{C}$ - chart, yang dapat dipergunakan memperkecil perbedaan mutu dari serat kapas dan untuk menentukan apakah ratio mixing kapas dapat dipcrbaiki atau mesin Blowing atau Carding perlu penyetelan.

4. Upper Control limit yang dapat dipergunakan adalah:

$$
C+3 \sqrt{C}
$$

\section{Pengendalian Sliver Carding}

Pengendalian sliver carding dilakukan dengan cara meng-check berat sliver, dan untuk itu diperlukan $\mathrm{X}$ dan $\mathrm{R}$ chart digunakan untuk menjamin produksi yang uniform dan normal. Berat sliver di test minimal satu kali seminggu tiap mesin, atau setiap ada mixing baru.

\section{Pengendalian Mesin Drawing}

Pengendalian mesin-mesin drawing meliputi checking berat sliver dan menekan putusnya sliver.

Pengendalian tersebut adalah sebagai berikut :

a. Kelembaban relatif dijaga pada standar 50-60\% 
b. Checking berat sliver dilakukan untuk tiap-tiap periode dua kali, yaitu pada permulaan dan pertengahan periode. Lamanya periode bisa $8 \mathrm{jam}$ atau lebih.

c. Hasil-hasil observasinya dibuat $\mathrm{X}$ dan $\mathbf{R}$ chart untuk berat sliver.

d. Checking putusnya sliver sebulan sekali untuk dapat menganalisanya tentang sebab-sebab putusnya dan seringnya putus, dan untuk dapat mengambil tindakan-tindakan guna pengurangan nya.

Cara pengambilan sample untuk observasi beratnya dilakukan sebagai berikut:

Dari tiap delivery tiap mesin drawing diambil dua kali tiap periode ( 8 jam) dan tiap pengambilan sepanjang 6 yard. Pengamatan berat sebaiknya dilakukan -dengan menimbang sliver tiap yard-nya, sehingga dapat diamati kerataan sliver dari yard ke yard. Pengambilan sebaiknya dengan jalan mengeluarkan can yang telah penuh dan kemudian sliver dibiarkan jatuh dilantai, jadi sliver belum dipengaruhi oleh pemutaran can. Sliver kemudian dipotongpotong menurut ukuran/yard, dikondisioner dan ditimbang.

Hasil-hasil pengamatan dapat dituangkan dalam lembar data dan control chart.

Lembar data berat sliver drawing biasanya berisi tentang:'

- Nomer-mesin

- Delivery

- Berat standar

- Berat nyata

- Rata-rata berat

- Range

\section{Pengendalian Mesin Speed}

Pengendalian mesin, speed pada prinsipnya adalah menjaga berat sliver Roving variasi agar selalu berada dalam contról limitnya, dengan jalan :

a. Tiap frame (mesin) diambil 4 babbin, untuk semua frama 24 jam sekali atau pada waktu gantu mixing ratio. '

b. Contoh diambil pada waktu start dan babbin penuh.

c. Pengamatan putusnya Roving dilakukan dari doff ke doff, untuk tiap mesin 15 hari sekali, sehingga tiap hari praktis mengamati 1 . (satu) mesin.

Lembaran data dan control chart yang diperlukan seperti berikut :

a. Lembaran data untuk berat Roving.

b. Control chart untuk berat Roving X dan $R$ chart

c. Lembaran data untuk test end breakage mesin speed

d. Control chart : C - chart.

6. Pengendalian Ring - Frame

Pengamatan yang harus dilakukan. pada mesin Ring-Spining adalah :

a. Pengamatan berat per lea.

b. Pengamatan twist per inch (TPI)

c. Pengamatan end breakage, baik dengan jalan pengamatan tiap frame tiap doffing dengan jalan memberi tanda pada tiap spendle yang tidak jalan, maupun dengan cara suap - read-ing.

d. Pengamatan kekuatan benang per lea.

e. Kalau ada alatnya maka yan evennes dan yarn appearance dapat juga dilakukan.

f. Pengamatan tentang waste dari seluruh proses.

\section{Daftar Bacaan}

1.Charnley Frank, "Manual of Cotton Spining", volume four part two, Draw Frames, Combers and Speed frams, The Textile Institute, 1964. 
2.N. Sügiarto Hartanto dan Sheru Freqnent faulis in Cotton Spining, Melleana Watanabe, "Teknologi Tekstil", P.T. Pradnya Textilberichte, 1973.

Paramita, Jakarta, 1980.

6.Sudjana, MA, MSc, DR, "Metode

3.Pawitro, S. Teks, dkk, "teknologi Statistika", edisi IV, Tarsito, Bandung, 1986.

Pemintalan", bagian 1 dan 2, Institut Teknologi

Tekstil, Bandung, 1975.

7.Uster News Bulletin No. 23, 1975 .

4.P. Supriyono, S. Teks, "Statistical

Chupter II Uster Statistics.

8.Wibowo Murdoko, S. Teks., dkk.,

Quality Control", Institut Teknologi Tekstil, Bandung, 1975.

"Evaluasi Tekstil bagian fisika", Institut

Teknologi Tekstil, Bandung, 1973.

5.P. Hattenschweler, H. Buhler, 